\title{
Nuées ardentes of 22 November 1994 at Merapi volcano, Java, Indonesia
}

\author{
E.K Abdurachman ${ }^{\text {ab }}$ J.-L Bourdier ${ }^{\text {ac }}$ B Voight ${ }^{\text {ld }}$
}

- ${ }^{a}$ UMR-CNRS 6530, Université d'Orléans, BP 6759, 45067 Orléans Cedex, France

- ${ }^{\mathrm{b}}$ Volcanological Survey of Indonesia, Jl. Diponegoro 57, Bandung 40122, Indonesia

- ${ }^{\mathrm{c}}$ Centre de Recherches Volcanologiques, OPGC, 5 rue Kessler, 63038 ClermontFerrand, France

- ${ }^{\mathrm{d}}$ Pennsylvania State University, University Park, PA, USA

\begin{abstract}
Nuées ardentes associated with dome collapse on 22 November 1994, at Merapi volcano traveled to the south-southwest as far as $6.5 \mathrm{~km}$, and collectively accumulated roughly 2.5-3 million cubic meters of deposits. The damaged area comprises $9.5 \mathrm{~km}^{2}$ and is covered by two nuée ardente facies, a conventional "Merapi-type", valley-fill block-and-ash flow facies and a pyroclastic surge facies. The proximal deposits reflect the accumulation of dozens of nuées ardentes, with many subsidiary flow units. The distal deposits are more simply organized, as only a few individual events reached to distances $>3.5 \mathrm{~km}$. The stratigraphic relationships north of Turgo hill indicate that the surge deposits are a facies of particularly mobile nuées ardentes that also deposited channeled block-and-ash flow facies. They further suggest that the surge facies beyond the channel margins correlate laterally with a finer-grained sublayer locally developed at the base of the block-and-ash flow facies. Eyewitness reports suggest that the emplacement of the block-and-ash flow facies in the distal part of the Boyong river may have followed, by a short time interval, the destruction and deposition of the surge facies at Turgo village. The stratigraphy is in accord with the eyewitness reports. The surge facies was emplaced by a dilute surge current, detached from the same dome-collapse nuee ardente that, as a separate flow unit, subsequently emplaced the distal block-and-ash deposit in the Boyong valley. The detachment occurred at higher elevations, likely at or above the slope break at about $2000 \mathrm{~m}$ elevation. This flow separation enabled the surge current to shortcut over the landscape and to emplace its deposit even as the block-and-ash flow continued its tortuous southward movement in the Boyong channel. Dome-collapse nuée ardente activity formed the bulk of the eruption, which was accompanied by virtually no significant vertical summit explosive activity.
\end{abstract}

\section{Keywords}

- nuées ardentes;

- Merapi volcano;

- block-and-ash flow;

- pyroclastic range;

- lava dome

\section{Introduction}

At Merapi volcano on 22 November 1994, a large number of dome-collapse nuées ardentes were generated over a period of several hours, after which the nuée ardente activity abruptly 
ceased. A portion of these nuées ardentes traveled southward, whereas previous nuées ardentes in 1984 and 1992 traveled exclusively toward the southwest and west. The 1994 nuées ardentes descended mainly the Boyong valley and the Bedog valley, a tributary of the Krasak-Kecil valley (Fig. 1). The largest nuée in the Boyong valley occurred about $45 \mathrm{~min}$ after the start of the eruptive activity and traveled as far as $6.5 \mathrm{~km}$. Collectively, the nuées ardentes damaged a sector of about $9.5 \mathrm{~km}^{2}$ on the south and south-southwest flank (Fig. 2), mainly between the Boyong and Krasak-Kecil valleys, and in adjacent areas (Abdurachman et al., 1995). They were responsible for 95 casualties in the vicinity of the Boyong valley, from the edges of Kaliurang and Turgo villages (Shelley and Voight, 1995). The nuées ardentes were accompanied by insignificant vertical plumes rising from the source area (Voight et al., $2000 \mathrm{c}$ - this volume), although some co-ignimbrite ash clouds rose several $\mathrm{km}$ above the region of deposition (Voight et al., 2000a - this volume). The nuées were exclusively generated by the collapse of large parts of the 1994 lava extrusion. Their collective bulk deposit volume is estimated to be about $2.5-3 \mathrm{Mm}^{3}$ (2-2.5 $\mathrm{Mm}^{3}$ dense rock equivalent). This interpretation is consistent with subsequent inspection of surface features of the dome (cf. Young et al., 2000 and Ratdomopurbo and Poupinet, 2000). 


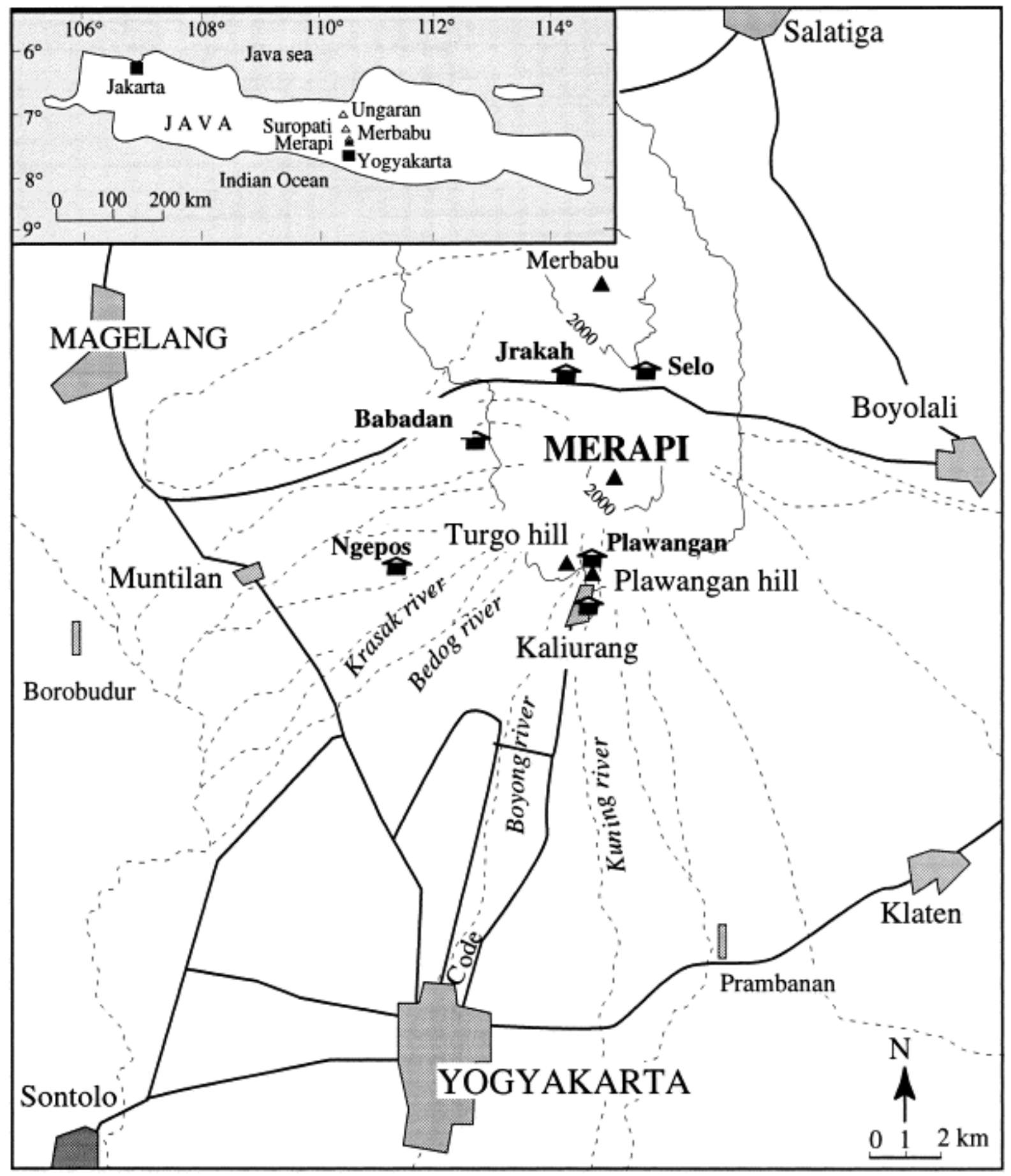

Fig. 1. Location map of the Merapi area. Solid triangles indicate Plawangan and Turgo hills. Hut symbols indicate VSI observation posts of Ngepos, Babadan, Jrakah, Plawangan, Selo, and the Kaliurang post newly established after the 1994 eruption to replace the unsafe Plawangan post. The Turgo village is located immediately south of Turgo hill, west of Kaliurang. Solid lines are main roads, dashed lines are main valleys. Inset drawing shows location of Merapi and other volcanoes of the Merapi chain in Java. 


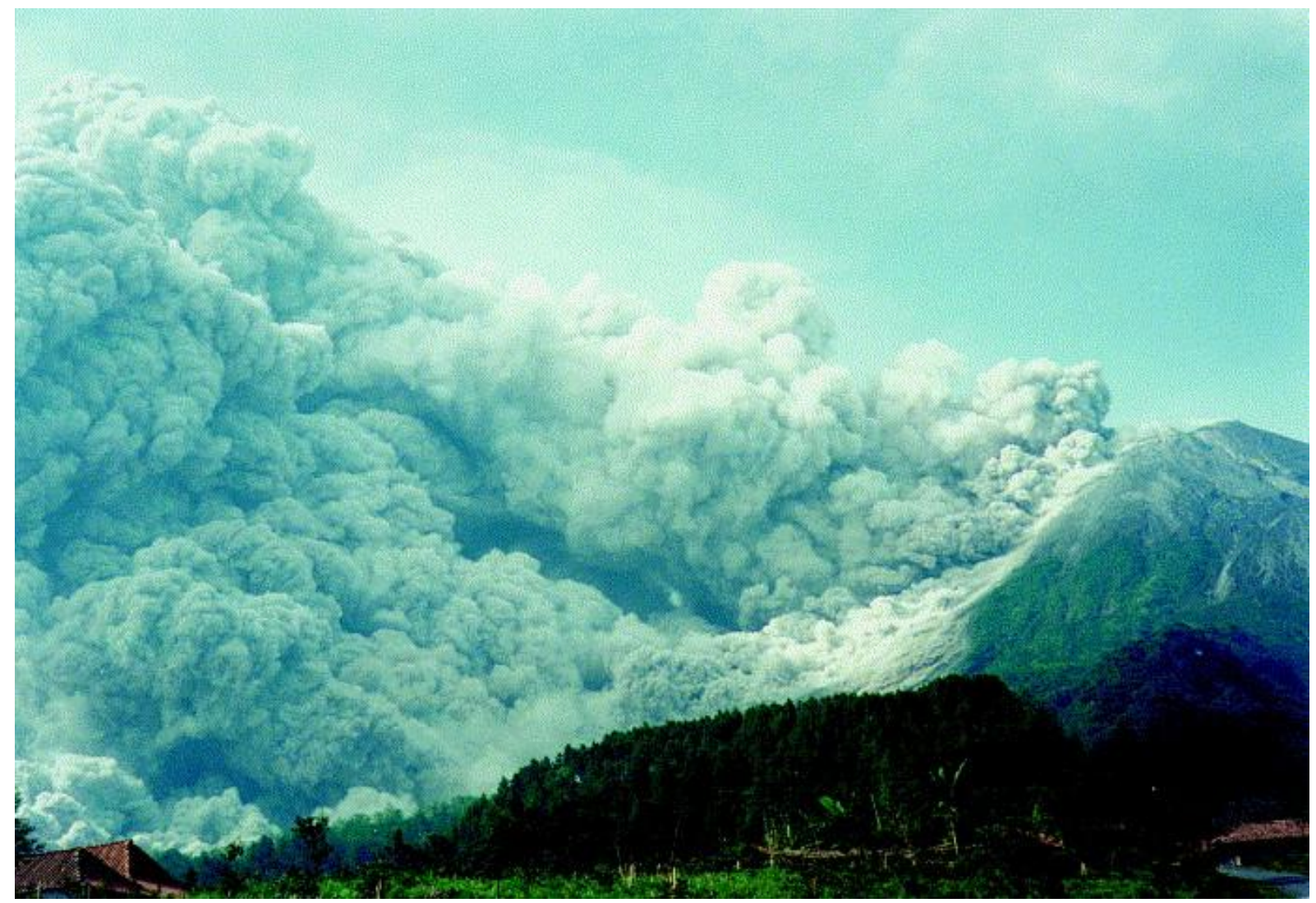

Fig. 2. Nuée ardente descending Boyong drainage area, as viewed from $2 \mathrm{~km}$ east of Plawangan hill. Time about 1400 to 1500, 22 November. View to northwest. (M Mongin photo).

Merapi volcano is, of course, famous internationally for nearly continuous lava dome activity and frequent, hazardous dome-generated pyroclastic flow eruptions. It has become the reference volcano for the so-called "Merapi-type" of pyroclastic flows, i.e. relatively smallvolume, low energy pyroclastic flows generated by gravitational collapse of parts of a lava dome (e.g. Escher, 1931, MacGregor, 1952 and MacDonald, 1972). However, despite the frequent reference in volcanological literature to "Merapi-type" pyroclastic flows at other locations worldwide, very few detailed observational reports of the eruptions of Merapi, including the timing, origin, and behavior of the pyroclastic flows, are available in the literature. Going back not earlier than the eruption of December 1930, the greatest in the 20th century, more than 25 pyroclastic flow eruptions of some importance have been recorded. But apart from the large and complex 1930 eruption that was more or less extensively studied (Neumann van Padang, 1933 and Voight et al., 2000b - this volume), only a few eruptions have been described in any detail. Among the latter studies are the events of 1954-1957 (Hadikusumo, 1957), 1967-1969 (Suryo, 1985), and 1984 (Sudradjat and Siswowidjoyo, 1987 and Boudon et al., 1993), and of these descriptions (mostly in obscure literature sources, Voight, 2000b - this volume), only the report by Boudon et al. (1993) discusses pyroclastic flow stratigraphy and sedimentology. Thus, despite the wide use of the term "Merapi-type" in volcanology, detailed descriptions of prototype Merapi events are virtually unavailable.

Because the 1994 eruption is in many respect representative of the Merapi's eruptive activity in the recent past, it provides an opportunity for a better description of "Merapi type" pyroclastic flows at their type locality. This paper is thus aimed at: (1) summarizing the 
available information on the chronology and character of the eruption, based on direct observations from the Volcanological Survey of Indonesia's (VSI) Merapi Volcano Observatory (MVO) observation posts and from local eyewitnesses (cf. Voight et al., 2000); (2) presenting a general description and map of the area of destruction (with some aspects treated in more detail in Kelfoun et al., 2000 - this volume), and (3) providing data on the relatively complex distribution, stratigraphy, sedimentology, and lithology of the 1994 nuées ardentes deposits. Our study illustrates the fact that Merapi-type events, of which the 1994 event was typical, are often more complicated than they are commonly considered to be.

A striking feature of some of the 1994 pyroclastic flows is that they comprised an unexpectedly large and destructive ash-cloud surge component (Fig. 2). Given this, we use herein for convenience the term "nuée ardente" (after Lacroix, 1904) as a general, descriptive term encompassing both pyroclastic surge and pyroclastic flow of modern terminology. The 1994 deposits include a pyroclastic surge facies and a block-and-ash flow facies (Abdurachman et al., 1994 and VSI, 1994), whose stratigraphic and emplacement relationships as detailed in this paper provide evidence of flow decoupling and detachment of the ash-cloud surge component from the valley-confined block-and-ash flow (Bourdier et al., 1997a and Bourdier et al., 1997b). The 1994 nuées ardentes of Merapi thus exemplify a decoupling process in small-volume pyroclastic flows that has been conceptually recognized (e.g. Fisher, 1979 and Fisher, 1995) but has hitherto been documented in only a few cases, e.g. at Ngauruhoe (Nairn and Self, 1978), Mount St. Helens (Hoblitt, 1986 and Mellors et al., 1988), and Unzen (Yamamoto et al., 1993 and Nakada and Fujii, 1993). Because of the potentially serious consequences of detached ash-cloud surges from even small-magnitude pyroclastic flows, there is currently a need for a better assessment of the factors associated with such decoupling, at Merapi and on andesitic volcanoes elsewhere.

\section{Direct observations of the 22 November eruption}

\subsection{Nuée ardente chronology}

The chronology of the nuées ardentes is based on eyewitness reports by MVO personnel located at the Plawangan observation post, atop the Plawangan hill (Fig. 1). The post, about $5 \mathrm{~km}$ from the summit, was very close to the nuées ardentes that descended the Boyong valley. Small block avalanches occurred without warning at 10:07 (all reported times are local). Then, a succession of eight nuées ardentes (nuées in the following) descended the upper parts of the Boyong and Krasak-Kecil valleys between 10:14 and 10:27, travelling at most $2.5 \mathrm{~km}$. Slightly longer nuées encroached also on the Kuning valley at 10:29 and 10:31. Between 10:33 and 10:46 six nuées were limited to about 1.25-2 km down the Boyong valley, but according to Plawangan observer interpretations, extended as far as $2.75 \mathrm{~km}$ in the Krasak drainage. However, one nuée was reported at 10:34 by a Ngepos post observer-who may have had a better view of this sector-to have reached $6 \mathrm{~km}$ to the southwest. At 10:50, a significantly larger nuée traveled about $4 \mathrm{~km}$ in the Boyong, nearly reaching the narrows between Plawangan and Turgo hills, and an unspecified length to the southwest in the KrasakKecil drainage. Another of unspecified length is noted at 10:52 in the Boyong and the approaches to the Kuning.

A still larger nuée followed at 10:54 and was seen entering the narrows between the Plawangan and Turgo hills. Searing of vegetation and a rain of ash at 10:55 around the Plawangan observatory accompanied this nuée, prompting the VSI personnel to evacuate the post for a safer position. No observation is then available until VSI personnel returned to the 
post at about 11:30. About 30 nuées were reported between 11:32 and 14:00, followed by about 18 more between 14:01 and 14:49 (Fig. 2). The largest of these occurred at 13:10, with runout reaching nearly to the Plawangan-Turgo narrows in the Boyong valley. VSI personnel were urged to leave the Plawangan post, and departed for Kaliurang at 15:08. Nuée activity apparently ceased around 17:00. Fig. 3shows the cumulative number of nuées reported by VSI observers from Plawangan post as a function of time. Photographs of some of this nuée ardente activity is reported in Voight et al. (2000a - this volume).

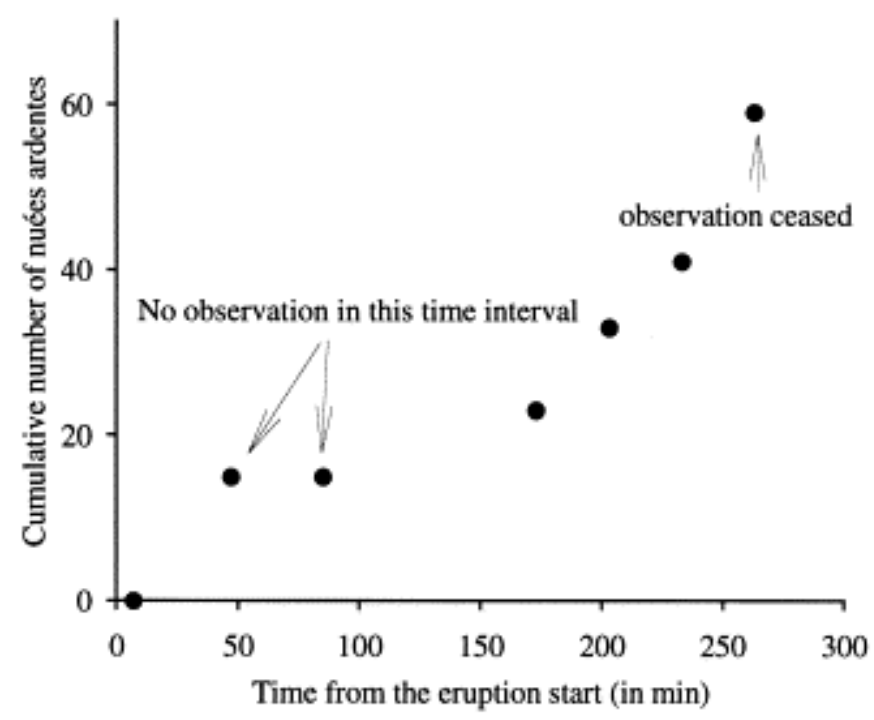

Fig. 3. Cumulative number of 22 November 1994 nuées ardentes reported by VSI personnel from the Plawangan post, as a function of time $(\mathrm{min})$ from the start of the eruption at 10:07. No observation was made between 10:55 and 11:32, and observations ceased at 15:08, although activity continued until about 17:00 (see text).

Reports from VSI personnel in more remote observation posts not facing the nuées (Babadan, Ngepos, Jrakah) (Fig. 1) are much less detailed, as most of the nuée activity was hidden from those locations. At Babadan post west of Merapi, 33 nuées were observed as discrete plumes, while 79 were interpreted from seismograph recording (along with 45 signals interpreted as rockfalls). The first nuée cloud was reported from here at 10:15. Larger plumes convecting upward from nuées were observed at 10:44, 12:46 (to $2600 \mathrm{~m}$ above the summit) and at 14:30 (to $4600 \mathrm{~m}$ above the summit). From Jrakah, on the north, a nuée plume was observed at 11:04 and estimated as $1000 \mathrm{~m}$ high above the summit, and some photographs were taken of co-ignimbrite ash clouds (Voight et al., 2000a - this volume). From Ngepos post, the first nuée was observed at 10:14, and a much larger one as mentioned previously at 10:34, after which visibility was much reduced.

\subsection{Summit activity}

All direct observations agree that the 22 November nuées ardentes were accompanied by little, if any, vertical explosive activity at the summit. A VSI field party was at the summit of Merapi in the morning of 22 November conducting a routine check of the volcano. They were on the northern part of the summit area and did not notice the start of the eruption, and were 
informed only after the eruption had started by radio warning from the MVO in Yogyakarta. Nuée ardente activity during the first hour, including the largest nuées to 10:50, was only recognized at the summit from rather weak and sporadic plumes rising above the lava dome (the dome was not within direct view of the field party). Those plumes were either white, gray or brown clouds a few hundred meters high, rising at intervals of a few minutes beginning around 10:15. No tephra fallout was experienced by the party, no lightning was observed, and no unusual noises were noticed to accompany the plumes. There was, however, a noticeable increase of the air temperature in the area. VSI observers from remote posts (Babadan, Jrakah, Ngepos) all confirm the lack of explosion sounds in those sectors, and lack of vertical explosive summit activity. The only plumes they observed were nuée ash clouds rising above the south flank. VSI personnel at Plawangan post noted sharp noises occurring at the initiation of the nuées at 10:33, 10:50,10:54, 14:43, and 14:47, with this latter being the loudest. They later recalled that vertical puffs from the vicinity of the dome, with similar coloration to the nuées themselves, accompanied the sharp noises. The puffs apparently originated at a constant location on the north-east side of the dome.

\subsection{Westward ash fallout}

Strong westward winds on 22 November displaced the largest co-ignimbrite ash plumes, and accounted for ash fallout on the west flank of the volcano as far as the town of Magelang. At Babadan post, ash fallout accompanied by darkness occurred between 10:35 and 11:00, producing a deposit about $5 \mathrm{~mm}$ thick of poorly sorted ash. At Ngepos post, ash fell in darkness between around 10:45 and 12:50. This was described as a continuous fallout of cold, poorly sorted ash smelling of sulfur, that left a poorly sorted deposit about $5 \mathrm{~mm}$ thick. Accretionary lapilli are not specifically mentioned in the post reports, but it is doubtful that they would have been recognized by post staff. Ash also fell north of the volcano at Jrakah post for about half an hour, at an unknown time.

\section{Area of damage}

We distinguish three zones in the area damaged by the nuées ardentes of 22 November on the basis of interpretation of oblique aerial photographs taken by MVO staff in December 1994 and BV in February 1995, other photographs, and field observations (Abdurachman et al., 1995) (Fig. 4). In the internal zone (1), or "tree blow-down zone", the vegetation has been completely stripped off or blown down, and is largely buried beneath the pyroclastic deposits. This zone mainly corresponds to portions of the south flank between 1150 and $2100 \mathrm{~m}$ a.s.l.; above this, there was no vegetation since the area had already been subjected to numerous rock avalanches (gugurans). The steep-walled ravines, partly filled by thick pyroclastic flow deposits, can be also included as a subdivision of zone (1). The medial zone (2) is an area of damaged trees and scorched vegetation, where trees are uprooted, irregularly broken, or bent. Although severely damaged, the vegetation in zone (2) is much more visible than in zone (1) owing to thinner deposits (on average). The boundary between zones (1) and (2) is transitional, with patches of destructive grade similar to zone (1) occurring within parts of zone (2). In general, damage tends to gradually decrease toward the outer boundary of zone (2). Tree damage is addressed by Kelfoun et al., 2000 and Clarke and Voight, 2000. 


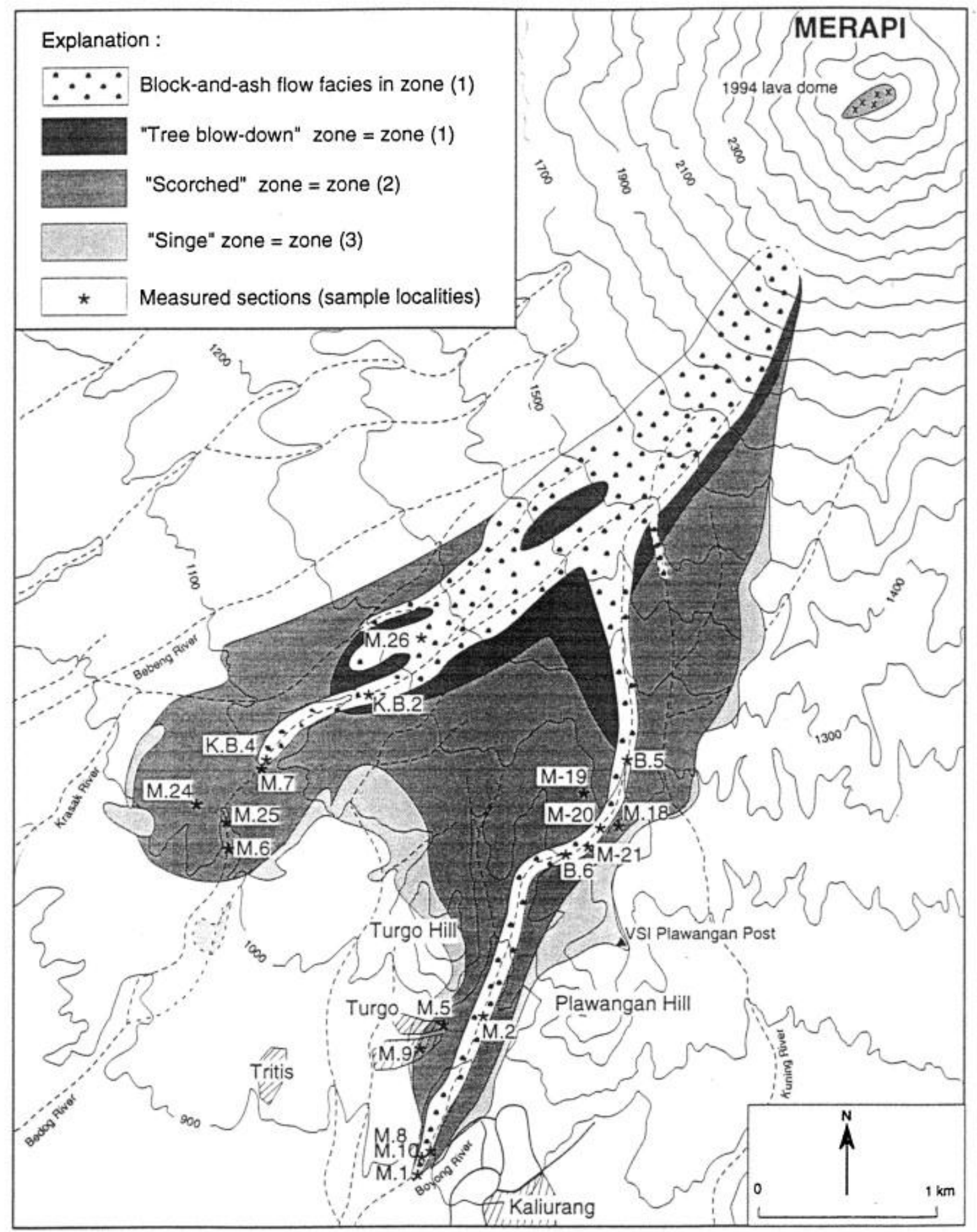

Fig. 4. Map of the damaged area, with zones (1)-(3) as described in text. The limit of the destruction coincides approximately with the original external limit of the surge facies.

Bent or uprooted trees consistently indicate downstream flow of the pyroclastic currents, and a general radial pattern of flow from the summit area. Local flow directions also occur that differ from the crater-radial direction, due to local topographic effects such as valley alignment. Beyond the Turgo and Plawangan hills, flow directions within low parts of the Boyong channel are essentially parallel to the local ravine walls. Higher on the valley walls 
the flow directions tend to diverge from the general valley axis by as much as $30^{\circ}$. Along the margins of the Boyong valley below the Turgo and Plawangan hills, and on the northern flanks of those hills, mechanical damage decreases, although irregularly, with increasing elevation. The west edge of Kaliurang, and the part of Turgo village where most casualties occurred, are located at the distal edge of zone (2).

The external zone (3) is a "singe zone", where trees and foliage were not mechanically damaged, but were seared by the heat of the clouds. The boundary between zones (2) and (3) is transitional and irregular, and is commonly characterized by a transition zone in which tree damage steadily climbs in elevation, such that only the upper parts of trees are broken or damaged as the outer limit of zone (2) is approached (cf. Clarke and Voight, 2000 - this volume). The outer boundary of zone (3) is very sharp and was still visible in most places 10 months after the eruption. Searing in zone (3) tends to climb with travel distance, and at the outer boundary only the tops of trees were seared.

\section{Distribution, facies and stratigraphy of the 22 November nuée ardente deposits}

Our field work on the 22 November deposits began in February (BV) and April 1995 (EKA, JLB) after heavy rains had already removed or reworked much of the deposits. Therefore, the complete original distribution of the deposits cannot be directly assessed with accuracy. Earlier mapping by MVO geologists recognized two nuée ardente facies in the damaged area, namely a block-and-ash flow facies surrounded by a pyroclastic surge facies, the limits of which roughly coincided with the damage boundary (VSI, 1995). There were also eyewitness reports of poorly sorted ash in the distal part of zone (2) and in zone (3) immediately after the eruption. We recovered primary (unreworked) surge facies locally at a number of localities, e.g. at Turgo village and in the Bedog valley. Based on this evidence, we infer that the distribution of the 22 November nuée ardente deposits originally coincided with the damaged area given in Fig. 4, apart from some thin fallout veneer deposits that were carried beyond the area of destruction.

Our inference is also consistent with evidence suggesting that the observed damage and related sedimentation in the distal parts of the affected area were caused mainly by surge-type emplacement of nuées ardentes. It is now well established that ground-hugging hot surges can devastate the landscape and simultaneously deposit material along their path, becoming more dilute with travel distance until they become buoyant and rise abruptly into the air. Such behavior is consistent with the progressive rise of tree-trunk damage near the zone (2)/(3) boundary, with the sharp external limit of the affected area (typically a singe zone), and with the rise in height of searing to tree-top level near the outer limit of zone (3). It is also consistent with the correspondence of this singe boundary with the deposit limit, as noted in other well documented surge eruptions such as the Mount St.Helens blast of 18 May 1980 (e.g. Moore and Sisson, 1981), the 8 May 1902 nuée ardente at Mt. Pelée (Bourdier et al., 1989), and the pre-plinian pumice surge of Kelut volcano on 10 February 1990 (Bourdier et al., 1997a and Bourdier et al., 1997b).

During our field work, we could only survey the distal part of the affected area, i.e. the lowest parts of the Boyong and Bedog valleys below $1270 \mathrm{~m}$ a.s.l., and adjacent ridges of both valleys. Frequent rock avalanches indicative of continuing dome growth and collapse at the summit prevented safe access to deposits at higher elevation. In the valleys, the block-and-ash flow deposits were well preserved. Outside the valleys, deposit textures were reworked in 
most places, but in some places we could measure sections where the primary surge facies was preserved.

\subsection{Block-and-ash flow facies}

A massive, unsorted, block-and-ash flow facies occurs as channel-fill deposits at the bottom of the Boyong, Bedog and Krasak-Kecil valleys, and in places between the valleys above $1200 \mathrm{~m}$ a.s.l. (Fig. 4). In the Boyong valley, the channel-fill deposits can be almost continuously followed from the deposit front (at $835 \mathrm{~m}$ a.s.1.) for about $1.5 \mathrm{~km}$ up through the narrows between the Plawangan and Turgo hills. By April 1995, erosion channels within these deposits had been incised to the pre-1994 level, providing excellent and nearly continuous exposures. A single block-and-ash flow unit was emplaced in this part of the Boyong valley. The deposit contains debarked tree trunks, limbs and branches. Some of the trunks and branches are converted to charcoal, but many are only surficially charred. The treetrunks are more abundant near the front of the deposit, and locally along banks and valley walls at the outside of meander bends. The deposit rests on older alluvium and is covered by post-eruption lahar deposits (Lavigne et al., 2000 - this volume).

Upstream from the narrows separating the Plawangan and Turgo hills, between 1100 and $1230 \mathrm{~m}$ a.s.1. along the Boyong channel (i.e. between 3.8 and $4.5 \mathrm{~km}$ distance from summit), the base of the 22 November deposits is locally exposed. Here there are at least four distinct block-and-ash flow units (Fig. 5). Where the block-and-ash flow facies wedge out along the pre-existing valley walls or intra-canyon banks, considered in a section transverse to the valley, a sharp facies variation occurs within a few meters. The variation is characterized by a rapid depletion in blocks, the development of a strong inverse grading, and a strong planar fabric of clasts aligned parallel to the bank walls. The planar fabric is mostly developed at the base of the flow unit and decreases in intensity upward. 


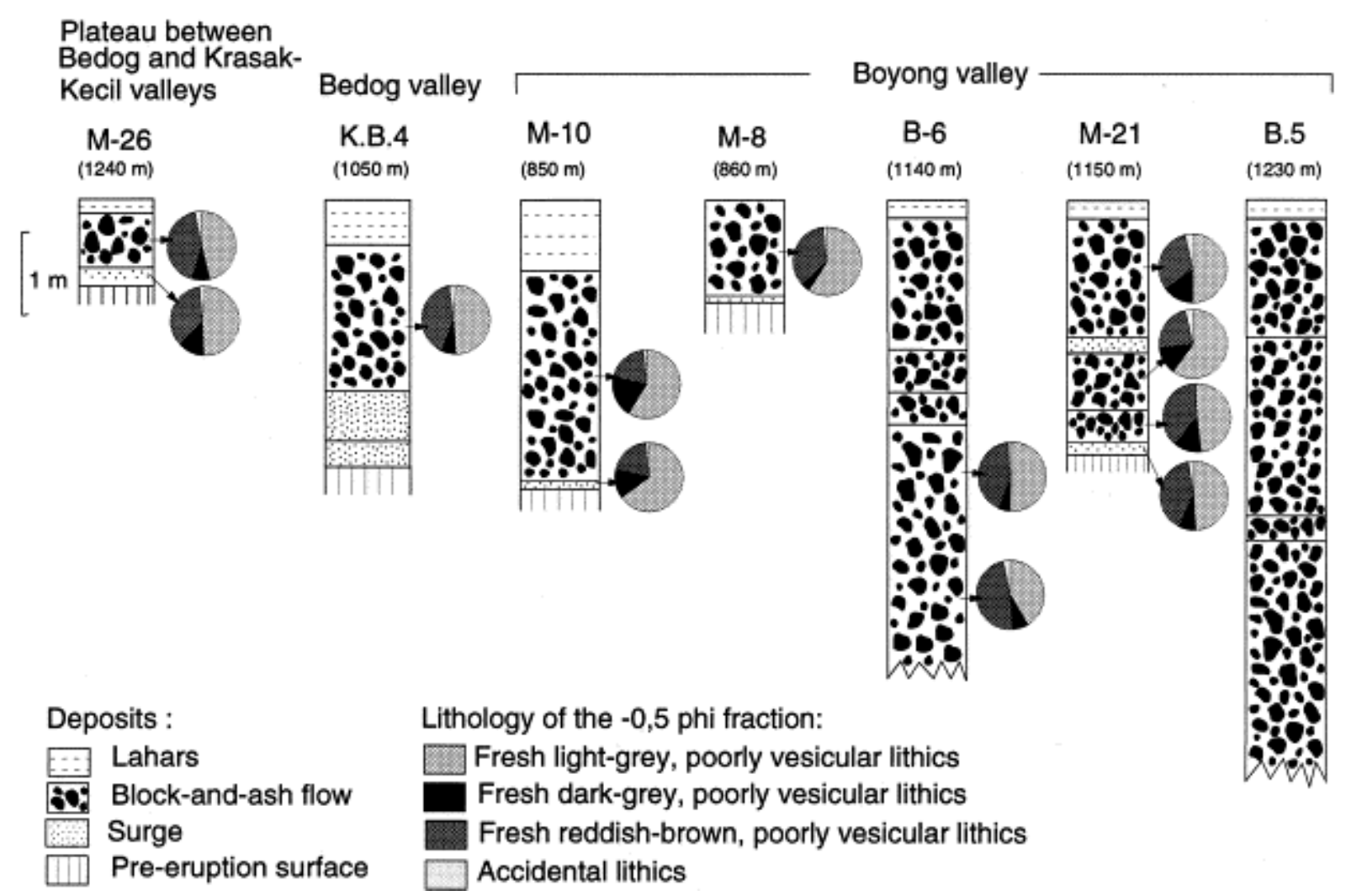

Fig. 5. Stratigraphic sections of the block-and-ash flow facies. Measured sections are located in Fig. 4. Lithological content (weight proportions) indicated for the $-0.5 \mathrm{phi}(1.4-2 \mathrm{~mm})$ sieve fraction of "spot" samples.

In the Bedog valley, a single block-and-ash flow unit was followed for a few hundred meters from its front, which is at $1050 \mathrm{~m}$ a.s.l. (Fig. 4). The flow is overlain by post-eruptive lahar deposits, and rests on two surge units. As at Boyong, the channel facies is a dark, block-rich, pyroclastic flow facies, which in the distal $100 \mathrm{~m}$ behind the flow front is enriched in metersized boulders and partially to fully charred tree trunks and branches. A chaotic assemblage of debarked, chiefly unscorched tree trunks and branches has accumulated at the very front of the deposit in the Bedog valley. Channel-fill block-and-ash flow deposits have also been recognized in the bottom of the Krasak-Kecil valley. Unchanneled block-and-ash flow deposits of lesser thickness occur in some areas outside the main valleys, e.g. on the plateau separating the Krasak-Kecil and Bedog valleys (M26, Fig. 5). These deposits are similar in texture and are approximately as block-rich as are channel-fill deposits, but maximum clast size is smaller.

\subsection{Pyroclastic surge facies}

In the Bedog valley below $1050 \mathrm{~m}$ a.s.l., beneath the front of and beyond the block-and-ash flow facies described previously (Fig. 4), are two superposed surge units (KB4 in Fig. 5, M6, M7, M25 in Fig. 6). The lower surge unit (S1) directly overlies the pre-1994 soil and consists of two discrete layers. The lower layer is a $2-6 \mathrm{~cm}$ thick, gray, open-work, slightly normally graded, poorly sorted ash with mixed soil and wood fragments. It is primarily sand-sized, but contains scattered lapilli as much as $3 \mathrm{~cm}$ diameter, and soil clots to $8 \mathrm{~cm}$, reflecting the 
exposure of upturned root-balls of toppled trees to concentrated erosion by the surge current. The fragmented wood is uncharred, but some twigs are scorched (darkened outer parts) and leaves are charred. The tendency is for the charred products to occur in the upper part of the layer, whereas thermally unaffected leaves and twigs occur near the base. The lower layer grades upward and is capped by the upper layer, with the contact defined by a sharp grain-size change and an erosion surface. Locally a veneer of shredded vegetation separates the two layers.

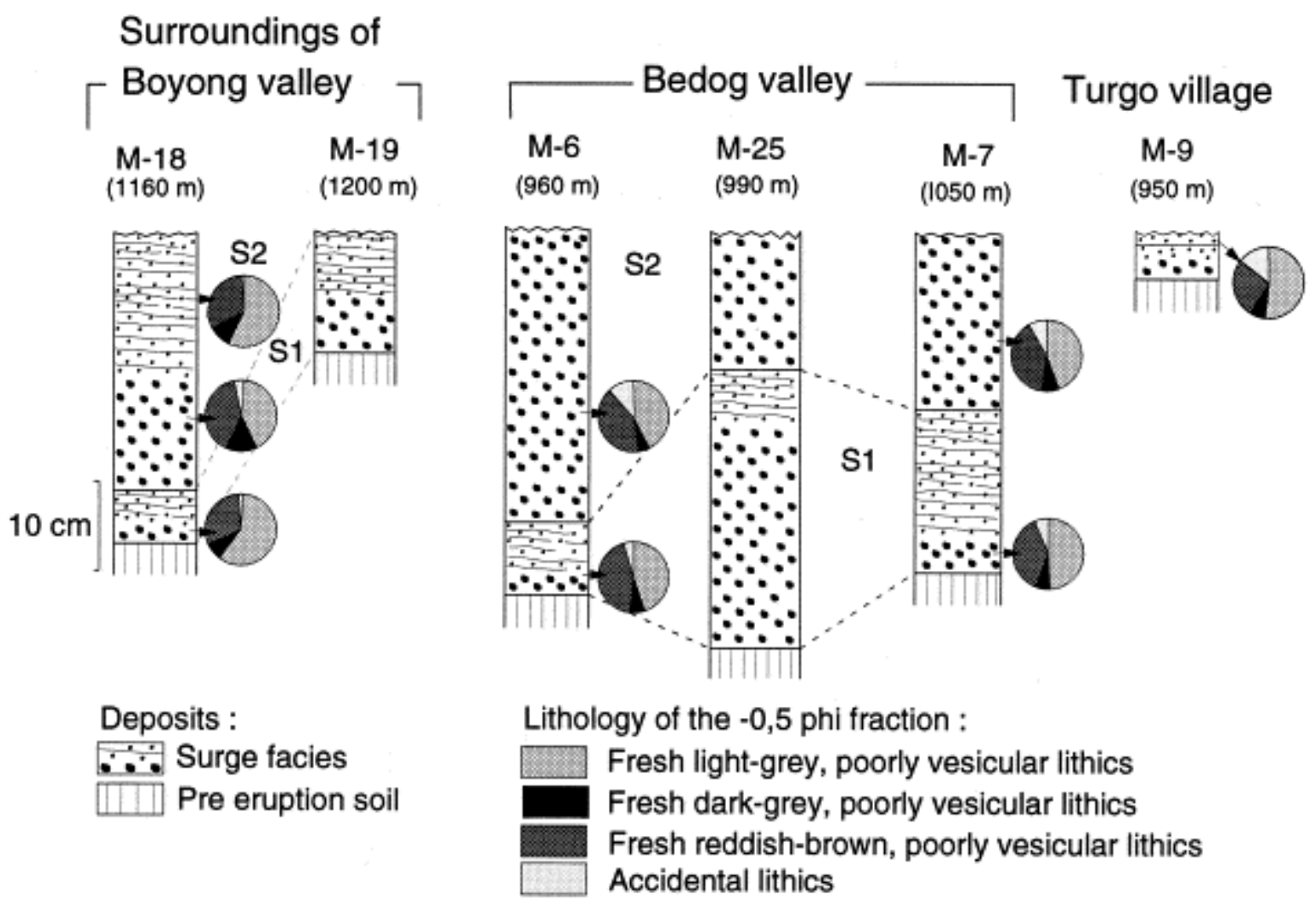

Fig. 6. Stratigraphic sections of the pyroclastic surge facies. Measured sections are located in Fig. 4. Lithological content (weight proportions) indicated for the $-0.5 \mathrm{phi}(1.4-2 \mathrm{~mm})$ sieve fraction of "spot" samples.

The upper layer, here termed the accretionary lapilli layer, is a brown, moderately well sorted, fine ash layer, $2-12 \mathrm{~cm}$ thick. This layer contains a zone of accretionary lapilli with diameters to $4 \mathrm{~mm}$. The individual grains that coalesce to form the lapilli are fine, with a typical diameter of coarse silt (4-5 phi; $0.031-0.062 \mathrm{~mm}$ ). The accretionary lapilli zone is laterally discontinuous, is locally unconformable, and in places shows evidence of plastic deformation. This zone occurs in some locations near the base of the upper layer and is overlain by laminations of finer ash (median diameter 6 phi; $0.016 \mathrm{~mm}$ ) with sparsely scattered lapilli. In other places, the accretionary lapilli zone is within the upper layer, and only locally does it occur at the top. Under the canopy of thermally injured trees in the singe zone, the accretionary lapilli layer is as thick as a $2-3 \mathrm{~cm}$ and overlies $0.5-1 \mathrm{~cm}$ of sandy tephra. The accretionary lapilli extend to the south beyond the limit of damage, where they may be found on the forest floor, locally mixed with $5 \mathrm{~cm}$ of loose fir needles, or wedged as lumps in the forks of trees. 
The upper surge unit in the Bedog valley (S2) is a gray, massive, normally graded layer. It is generally $15-20 \mathrm{~cm}$ thick beyond the block-and-ash flow facies, but up to $60 \mathrm{~cm}$ thick just beneath the block-and-ash flow facies in section KB4 (Fig. 5). It is primarily sand-sized and contains scattered lapilli as much as $6 \mathrm{~cm}$ diameter. It also contains both uncharred and scorched vegetation, but in lesser amount than in the lower surge. At a given section, it is coarser and thicker than the lower surge unit. Its top is generally eroded, with an exception near KB4 where it is preserved under the block-and-ash flow unit. There, the surge unit is unstratified to the top, and is capped by a $5 \mathrm{~mm}$ thick continuous layer of stratified fine ash. The surge unit contains numerous small vertical degassing pipes that originate in its basal part, and terminate at or near the top. It also contains a few scattered accretionary lapilli, of similar size to those found in the lower surge unit. These suggest the possibility that the second surge was emplaced while some accretionary lapilli, formed in the first surge cloud, were still falling.

The lower surge unit S1 can be traced in the kilometer-wide region north of Turgo hill. Its basal layer is a gray, compact, poorly sorted sandy ash with mixed soil and wood fragments, $2-6 \mathrm{~cm}$ thick, overlain by the brown accretionary lapilli layer, $2-4 \mathrm{~cm}$ thick. The latter is sharply overlain by a gray, loose-textured layer of cross-laminated sand-sized ash. Bubble vesicles occur to $15 \%$ by volume, and this layer clearly has been reworked by monsoon rainstorms. This layer probably represents the reworked products of the upper surge unit S2 found in the Bedog valley.

In Turgo village, the nuées ardentes deposits comprise two layers (M9 in Fig. 6), an olive brown, compact, massive, poorly sorted, medium-sized ash 2-6 cm thick, blanketed by a cmthick layer of gray, well-sorted coarse ash and lapilli. The Turgo residents reported that only one nuée ardente event affected their community, suggesting that the deposition of both layers was nearly contemporaneous. The lower layer is normally graded and contains mixed soil grains, scattered soil clumps and clasts to $5 \mathrm{~cm}$, wood fragments, twigs, and leaves. Some twigs and leaves have been scorched, with the outer bark of many twigs darkened. Many of the clasts are not fresh, showing indications of weathering. They, the overall deposit color, and the soil clumps, reflect erosion and entrainment of soils by the surge, aided by the toppling of vegetation and the subsequent exposure of rooted soil and weathered old tephra to the erosive current. The boundary between the two layers is sharp. The upper layer is distinctive by its color, loose texture, coarser mean grain size, and sorting. The grains are dominantly fresh, with scattered lapilli as large as several centimeters. The grains were emplaced hot, and caused contact melting of plastic (Voight and Davis, 2000 - this volume).

Turgo residents located in the very distal part of zone (2) or in zone (3) during the eruption confirm that the deposit was initially about $5 \mathrm{~cm}$ thick in open areas. Emplacement of the ash and lapilli caused significant structural damage to houses, toppling masonry walls, stripping tile roofs, and demolishing bamboo huts. Ash penetrated the houses, and several $\mathrm{cm}$ of ash accumulated on floors. The deposit was burning hot for about 5 min after deposition, and remained hot for hours afterward, although people could already walk over it. Eyewitnesses reported that falling grains were incandescent.

In the Boyong valley below the Plawangan-Turgo narrows, an ash layer has been recognized at several sections beneath the block-and-ash flow unit (M8, M10 in Fig. 5). This ash layer is massive, virtually ungraded, moderately well sorted, dominantly fine ash. It is only $1 \mathrm{~cm}$ thick at the most distal section (M8), $100 \mathrm{~m}$ from the front of the block-and-ash flow unit. This 
layer rests directly on the pre-eruption basement. It must correlate with the lower (surge) layer found just outside the valley wall, within Turgo village.

North of the Plawangan-Turgo narrows, the surge facies occurs on each side of the Boyong valley and is locally more than $30 \mathrm{~cm}$ thick. The lower layer is a poorly sorted, openwork, dominantly sandy layer rich in uncharred to slightly tanned vegetation debris and containing mixed soil clots. This lower layer is irregular in thickness and only a few centimeters thick. It is overlain with an erosive contact by a crudely laminated, finer-grained, ash-dominated upper layer, $2-3 \mathrm{~cm}$ thick. We interpret both layers as forming a lower surge unit, similar in some respects to the double-layered lower surge unit in the Bedog. However, it cannot yet be excluded that the deposits could represent two distinct surges, or even that the second layer could be a compound deposit from several minor surges. The third layer is much thicker (10 cm on average) and coarser, an unsorted, massive, openwork, sand-rich layer with scattered lapilli to $4 \mathrm{~cm}$ diameter, and charred wood fragments. The layer is apparently nongraded, apart from the uppermost part that in places grades into a brown laminated ash a few $\mathrm{cm}$ thick (possibly reworked). This third layer is interpreted as a second surge unit, the thickest of the sequence. Above this are about $10 \mathrm{~cm}$ of laminations, consisting of $\mathrm{cm}$-thick layers of fine ash and poorly sorted coarse ash with sparse lapilli, probably representing thin surge and associated ash-cloud deposits, locally reworked.

\subsection{Lithologic analysis}

Components of representative samples of both facies have been separated, counted and weighed in selected sieve fractions (Fig. 5 and Fig. 6). As expected in Merapi-type deposits, the components are dominantly fresh, poorly vesicular, crystalline lithics, apparently derived from the 1992-1994 dome complex, with a related additional proportion of free crystals in the ash fraction. Only a few fragments are of weathered or oxidized material, or of otherwise distinctive lava types, classified as likely accidental. Differences in vesicularity and coloration occur among the fresh lithics, although the variations are more or less continuous. Fresh lithics have been separated into light gray, dark gray and reddish brown; the dark gray and reddish brown lithologies are on average slightly more vesicular than the light gray lithology. The significance of these lithological variations needs petrological and textural investigations which are beyond the scope of this paper. Here we have tried to use the relative proportions of different fresh and accidental lithic types as a potential aid to stratigraphic correlation. However, the lithological variations we find between depositional units are not consistent enough to support unequivocal correlations.

\section{Emplacement relationships of surge and block-and-ash flow facies}

The emplacement relationships of the block-and-ash flow facies and the surge facies are at least partly resolved, based on stratigraphic relationships and timing constraints from the eyewitness reports and seismological data. From this evidence, we suggest that the surge facies, found outside the channels that are now occupied by block-and-ash flow facies, resulted from early flow decoupling and detachment of a surge component; the surge deposits were emplaced ahead of block-and-ash flows that were mostly channeled in the valleys.

Eyewitness reports provide useful evidence concerning the nuée ardentes that bypassed the Plawangan and Turgo hills (see Voight et al., 2000). The VSI personnel of the Plawangan post reported only one nuée ardente, at about 10:54, bypassing the hills in the Boyong valley and thus able to destroy Turgo village. This evidence indicates that a single nuée event 
produced both the block-and-ash flow unit in the valley below ca. $1200 \mathrm{~m}$ a.s.1., and the surge deposit of Turgo village.

On the other hand, independent witnesses located in Kaliurang, looking up-valley, described a succession of two clouds bypassing the hills. The first one was described as a dark cloud that overtopped Turgo hill, scorched its east side and entered Turgo village. The second cloud was similar in appearance, apparently was centered above the Boyong channel and did not go into Turgo village, and descended further along the Boyong valley than did the first cloud. One of the witnesses, located at the Kaliurang viewpoint above the Boyong valley, was hit by the second cloud, whereas the first one did not reach him. According to another witness just beyond the destruction area in Turgo village, the first cloud destroyed Turgo then lifted into the air, with some visibility restored about him before he could see a cloud southeast of his position, moving down the Boyong valley. Although at variance with reports from the VSI Plawangan post (possibly reflecting the different positions and scales of observation), the different reports from witnesses more to the south are mostly consistent one with the other, and provide confidence that two closely spaced clouds bypassed the Plawangan and Turgo narrows. The reports further suggest that the surge deposit in Turgo village could be due to the first cloud, while the emplacement of the block-and-ash flow unit in the Boyong valley could be associated as a source of the second cloud.

In summary, eyewitness reports from Kaliurang and Turgo village suggest that the surge (and its related deposit) at Turgo preceded, by only several tens of seconds to a minute, the emplacement of the block-and-ash flow deposit in the Boyong channel below Kaliurang. The surge cloud may have descended also into the channel, to deposit a thin layer subsequently overrun by the massive, channeled block-and-ash flow. This scenario is consistent with our recognition of a discrete fine-grained layer of surge facies affinity beneath the block-and-ash flow unit, as described above. Because there is no report of any ash deposition on Turgo village before this was hit by the surge cloud, the surge deposit at Turgo obviously comprises the lower layer observed there (M9 in Fig. 6). On the other hand, the block-and-ash flow in the Boyong was accompanied by a "co-flow" ash cloud, as suggested by the eyewitness accounts. We suggest this "co-flow" cloud is represented in the deposit stratigraphy of Turgo village by the $\mathrm{cm}$-thick upper layer. This layer is coarser grained (coarse ash and small lapilli) and better sorted (i.e. fine-depleted) than the lower surge layer, and was very hot (c. $\left.300^{\circ} \mathrm{C}\right)$ when deposited (Voight and Davis, 2000 - this volume). This evidence suggests a nearby source, in accord with the above interpretation.

Overall, the eyewitness reports and stratigraphic relationships can be integrated into a consistent interpretation for the emplacement of the largest nuée at 10:54, the only one having bypassed the Plawangan and Turgo hills and having caused casualties in the Kaliurang-Turgo area. Such an interpretation also allows us to resolve the apparent contradictions between reports from VSI personnel at Plawangan observation post, and other eyewitnesses. We propose that the surge at Turgo represents a flow component associated with the same nuée ardente event (partial dome collapse) that produced the block-and-ash flow in the Boyong channel, but that a separation of the surge component occurred higher on the volcano flank. Because the Boyong channel follows a tortuous path at higher elevations, a separated surge component could descend the slope along a more direct, shorter path, and thus could arrive at a downvalley location before the arrival of the block-and-ash flow. In this model, the surge facies (lower layer) at Turgo village strictly correlates laterally with the ash basal layer in the Boyong channel, while the block-and-ash flow facies in Boyong strictly correlates laterally with the upper ash layer in Turgo, as equivalent (i.e. synchronous) depositional units. All 
these deposits, however, actually represent a single nuée ardente (or eruptive) unit, so that facies at various localities could be regarded as stratigraphic equivalents in a broad sense.

Similar stratigraphic relationships of the surge facies and block-and-ash flow facies can be inferred from the facies variations observed in the channel-fill deposits of the Boyong valley, north of the Plawangan-Turgo narrows. Block-and-ash flow units can be discontinuously traced in the valley bottom between 3.8 and $4.5 \mathrm{~km}$ from the summit. In two of these units, we have observed a distinctive, generally massive but locally crudely laminated, poorly graded basal layer of poorly sorted ash with scattered lapilli as large as $5 \mathrm{~cm}$ (e.g. M21 in Fig. 5). The sharp lower contact of these basal layers and their transitional upward-grading into the blockand-ash facies suggest that the finer basal layers belong to the same nuée ardente unit as the overlying block-and-ash flow facies. In one section, a basal finer-grained layer has been observed in direct contact with the pre-eruption surface. The contact was sloped, and the basal layer irregularly but continuously mantled it. It consisted of unsorted, openwork ash and lapilli, typically 5-10 cm thick. This well-defined horizon contained soil clots and abundant bent and broken, uncharred to charred branches that pierced into the overlying, apparently gently emplaced block-and-ash flow facies. Soil incorporation, mechanical destruction and irregular charring of the vegetation in this case are similar to those in the lower surge unit on the interfluves outside the valley. The lithology and grain-size of the basal layer in the channel compare very well with those of the interfluve lower surge unit elsewhere in this vicinity of the Boyong, except that the basal layer in the channel lacks a stratified finergrained upper part. The basal layer in the valley, under the block-and-ash flow deposit, may thus be correlated with the lower part of the surge outside the valley. The presence of a stratified finer-grained top outside the valley and its absence within the valley may be suitably explained by assuming that the upper fine-grained material accumulated outside the valley from upper parts of the surge cloud, while within the valley the emplacement of the blockand-ash flow occurred before the fines had time to settle out from the surge.

\section{Stratigraphic correlations among nuée ardente units}

In the preceding section, we have examined the correlations between the surge facies and the block-and-ash flow facies at the scale of a nuée ardente unit. Here we examine the possible stratigraphic correlations among the few nuée ardente units observed in the surveyed distal area, i.e. beyond $3.5 \mathrm{~km}$ distance from the summit. In the absence of a recognized lithologic criterion to discriminate between these units, correlations can only be based on chronologic constraints from direct observations, and on field criteria.

North of the Plawangan and Turgo hills, there are at least two pyroclastic surge units aside the Boyong valley (e.g. M18 in Fig. 6), correlating with two of the at least four nuée ardente units recognized inside the valley. We correlate the upper surge unit with the surge unit south of the hills, e.g. in Turgo village, thus attributing it to the largest nuée ardente, reported at 10:54. Two lines of evidence support this correlation. First, the upper surge unit is the thickest and coarsest in the area. Secondly, accounts from the VSI post at Plawangan report that some damage had already occurred in the area just north of Turgo hill before the occurrence of the nuée of 10:54. We thus interpret the lower surge unit beside the upper Boyong valley to a nuée ardente prior to 10:54. A strong candidate is the nuée reported at 10:50 by VSI observers at Plawangan, which achieved a runout "greater than $\pm 4000 \mathrm{~m}$ ". Alternative possibilities concern the nuée at about 10:34, or both 10:34 and 10:50, depending on the interpretation placed on the lower layers. 
There is a broad similarity between the Bedog and Boyong areas as there seems to be two main surge units in both areas. This similarity makes it tempting to directly correlate the two surge units of these valleys. However, a significant difference concerns the presence of accretionary lapilli in both surge units of the Bedog area, most especially in the lower unit. The accretionary lapilli layer of the lower surge unit in the area west of Turgo hill to the Bedog valley represents fallout deposition from a more or less vertical plume convecting above an associated nuée ardente, thus providing a time break and key stratigraphic marker for this sector. Its distribution may partly reflect atmospheric wind directions. By contrast, no accretionary lapilli layer was found at Turgo village nor in the vicinity of the upper Boyong valley, although it was carefully searched for. As a result the correlation between the accretionary lapilli layer and surge deposits beside the Boyong valley is not fully established.

An observation relevant to this discussion was made by an eyewitness in Turgo village, who reported a moving ash cloud west of Turgo hill, above the Krasak area, at the same time as the devastating surge cloud (of 10:54) was descending between the Plawangan and Turgo hills. This observation suggests that the greatest Boyong nuée of 10:54 likely emplaced a surge facies also in the Bedog and Krasak area, so that one of the surge units in the Bedog would correspond to the 10:54 nuée and thus correlate with the Boyong upper unit. The most likely possibility is that the second (upper), much thicker surge unit in the Bedog valley corresponds to a southwestward-directed lobe of the large 10:54 nuée, thus correlating with the second (upper) surge unit of the upper Boyong area. The lower surge unit of the Bedog area (containing the accretionary lapilli layer) may then correspond, as does the lower unit of the upper Boyong area, to either the 10:34 or 10:50 nuée. The above uncertainty leaves very different time separations between the two surges of either 20 or only $4 \mathrm{~min}$, for the accretionary lapilli layer to have accumulated.

The above interpretation is consistent with the view that the first major surge to reach any area could shred and cook the vegetation and vaporize dew, liberating moisture to locally saturate an ash plume. Condensation could then promote the generation of accretionary lapilli. Assuming a nominal lapillus diameter of $1 \mathrm{~mm}$ and a specific gravity of 1.3 , the terminal fall rate is about $4-5 \mathrm{~m} / \mathrm{s}$, so that lapilli could fall out of a $1 \mathrm{~km}$ plume in 3-4 min. Fallout from a relatively highly concentrated ash cloud a few hundred $\mathrm{m}$ high could occur even more rapidly, and thus the presence of accretionary lapilli does not in itself enable discrimination of the 10:34 and 10:50 nuées. However, finer material commonly overlies the accretionary lapilli, and the fall rate of 4-phi fines is only about $0.2 \mathrm{~m} / \mathrm{s}$. Thus several tens of minutes would be required to deplete much of an ash cloud only several hundred $\mathrm{m}$ high, and this evidence favors the interpretation that the two Bedog surge units represent nuées at 10:34 and 10:54.

\section{Conclusions}

The 1994 nuées ardentes traveled to the south-southwest as far as $6.5 \mathrm{~km}$, and accumulated collectively roughly $2.5-3 \mathrm{Mm}^{3}$ of deposits. By comparison, the 1984 nuées ardentes traveled southwest as far as $7 \mathrm{~km}$, and accumulated collectively $4.5 \mathrm{Mm}^{3}$ (Sudradjat and Siswowidjoyo, 1987). The area damaged in 1994 is covered by two contrasting nuée ardente facies, i.e. a valley-fill block-and-ash flow facies and a pyroclastic surge facies. The deposits are complex, as they were produced by the accumulation of dozens of nuées ardentes, representing sequential partial collapses of the active lava dome. The distal deposits are more simply organized, as only a few individual events reached to distances $>3.5 \mathrm{~km}$. 
Eyewitness reports suggest that the emplacement of the block-and-ash flow facies in the distal part of the Boyong valley may have followed, by a short time interval, the destruction of Turgo village and emplacement of the surge facies in that area. Stratigraphic data for the Boyong channel indicate the occurrence of a discrete fine-grained layer beneath the blockand-ash flow facies that we correlate with the surge (lower unit) of Turgo village. The hot cmthick upper layer at Turgo village was deposited by the second cloud reported by the eyewitnesses, and had as its local source the block-and-ash flow in the Boyong valley. Thus the stratigraphy is in full accord with the eyewitness reports.

In the Boyong valley north of the Plawangan-Turgo narrows, some block-and-ash flow units exhibit a distinctive basal layer consisting of poorly sorted, massive ash, with sparse lapilli. This basal layer has sedimentological characteristics that match the surge facies on the interfluve beyond the valley margin, containing soil clots and uncharred to slightly charred wood where in contact with the pre-1994 basement. The basal layer in the channel is transitional into the superjacent block-and-ash flow deposit, whereas it lies in sharp contact with the underlying units. Thus the stratigraphic evidence suggests that the overbank surge facies passes by transition in the valleys into a distinctive basal layer of some block-and-ash flow units. The evidence implies that the surge facies is separately deposited from the same nuée ardente that subsequently emplaced a block-and-ash flow deposit in the valley.

Thus, good evidence from stratigraphic data and direct eyewitness observations of the eruption indicates that the surge facies and block-and-ash flow facies are both facies of individual nuée ardente deposits. The surge facies was emplaced by a dilute surge current, detached from the same discrete dome-collapse nuée ardente whose channeled basal part, in the tortuous Boyong valley, resulted in emplacement of a block-and-ash flow deposit. The separation of the overriding expanding surge cloud from the dense coarse basal flow occurred well upvalley from the Plawangan-Turgo narrows. The scorched surge zone extends along most of the south wall of the avalanche chute under the unstable dome, with some accentuation where the south-directed lobe of the block-and-ash flow overtopped the wall (Fig. 4). Flow separation was likely aided by large-scale roughness of the flow path, particularly in the zone of wall overtopping. Thus, the surge currents were able to separate from the coarse basal flows and could pass across the interfluve landscape. The south lobe of this surge flowed toward and around Turgo Hill to emplace its deposit even as the channeled block-and-ash flow, blocked from spreading out by the steep Boyong ravine topography (less than $20 \mathrm{~m}$ deep in that sector), continued its tortuous southward movement. In this case the ash cloud surge was able to outrun the dense flow. Within some channel locations, the surge deposits were soon overlain by the corresponding block-and-ash flow unit.

Observations of the summit domes after the eruption by VSI personnel and others suggest that the 1994 nuées ardentes involved mainly the 1994-extruded portion of the 1992-1994 dome complex. Direct observations of the 1994 eruption, some made at very close range, indicate that the dome-collapse nuée ardente activity formed the bulk of the eruption and was accompanied by virtually no vertical explosive activity from the summit. Thus the nuées ardentes were almost fully motivated by gravity, and this is in accord with the lack of shortterm eruption precursors (Voight et al., 2000a - this volume).

Given the lack of direct evidence for significant explosivity in the 1994 eruption, why were a few nuées distinctly more mobile than others, producing a widely distributed surge facies in addition to (typically) channeled block-and-ash flow facies? It is likely that the more mobile nuées gained their mobility from a mass with higher initial energy, e.g. due to larger mass, 
and also possibly to higher temperature, or (possibly) higher volatile content of the lava involved. The latter aspects are uncertain, but it is most likely that the most mobile nuées were the largest in terms of volume and thus mass. This is consistent with the stratigraphic information, and with seismological data that indicate the highest seismic energy release at about 10:54, with this single event accounting for a tenth of the total collapsed mass (Brodscholl et al., 2000 - this volume).

In a more general perspective, the 1994 Merapi nuées ardentes provide further evidence of major current decoupling in small-volume pyroclastic flows with detachment of highly mobile, topography-mantling ash-cloud surges. Along with other recent examples of smallvolume, dome-collapse pyroclastic flows at Unzen (Yamamoto et al., 1993, Nakada and Fujii, 1993 and Fisher, 1995) and Montserrat (Cole et al., 1998), the 1994 nuées ardentes at Merapi draw attention to the very important hazard from surge detachment from dome-collapsegenerated block-and-ash flows.

In some respects, the 1994 Merapi event and the other cases cited above suggest a link toward even more violent and more destructive nuées ardentes such as those experienced in the period May-August 1902 at Mont Pelée. The Mont Pelée events have been interpreted as being very violent (high velocity), essentially turbulent and topography-escaping currentsthat is, basically, energetic pyroclastic surges - comparable in their flow behavior (although not in eruptive mechanism) with the 1980 Mount St. Helens blast (Bourdier et al., 1989, Boudon and Lajoie, 1989 and Lajoie et al., 1989), rather than with ash-cloud surges detached from channeled block-and-ash flows (Fisher et al., 1980 and Fisher and Heiken, 1982). A large explosive component due to spontaneous disintegration of gas-pressurized vesicles, was apparently added to gravitational energy in driving the large Mont Pelée nuées ardentes, and this accounts for their more energetic flow behavior compared to the 1994 Merapi nuée and other recent events.

\section{Acknowledgements}

Work by E.K.A. and J.L.B. was supported by the French Ministry of Foreign Affairs (MAE) and C.R.V.B.V.'s work on these deposits was initiated as part of the Volcano Crisis Assistance Team (VCAT, US Geological Survey-U.S. AID) response to the Merapi emergency in February-March 1995, with subsequent work supported by the National Science Foundation. Field work was aided by strong logistical support from the VSI Directorate in Bandung, thanks particularly to Drs Wimpy Tjetjep and R. Sukhyar, and from MVO in Yogyakarta, thanks to Dr M.A. Purbawinata. VSI scientists A. Ratdomopurbo, D. Sri Sayudi, J. Sulistiyo, S.D. Andreastuti and Made, generously provided information about the eruption and photographs of the affected area. VSI post observers Panut, Sugyito, and Rekio, and Christian Awuy of Kaliurang, among others, provided important eyewitness information. Other important assistance was provided by Franck Lavigne, Kirby Young, Michel Dejean, and Karim Kelfoun. Willie Scott and Wendell Duffield of USGS provided manuscript reviews for which we are most grateful.

\section{References}

Abdurachman et al., 1994

Abdurachman, E.K., Bourdier, J.-L., Purbawinata, M.A., 1995. Preliminary observations of the distribution and field characteristics of the November 22, 1994, nuée ardente deposits, Merapi volcano, Indonesia. Proceedings of the Merapi Decade Volcano 
International Workshop, UNESCO/Volcanological Survey of Indonesia, Yogyakarta, pp. 78-87.

Boudon and Lajoie, 1989

G. Boudon, J. Lajoie

The 1902 Peléean deposits in the Fort Cemetery of St. Pierre, Martinique: a model for the accumulation of turbulent nuées ardentes

J. Volcanol. Geotherm. Res., 38 (1989), pp. 113-129

Boudon et al., 1993

G. Boudon, G. Camus, A. Gourgaud, J. Lajoie

The 1984 nuée-ardente deposits of Merapi volcano, Central Java, Indonesia: stratigraphy, textural characteristics, and transport mechanisms

Bull. Volcanol., 55 (1984), pp. 327-342

Bourdier et al., 1989

J.L. Bourdier, G. Boudon, A. Gourgaud

Stratigraphy of the 1902 and 1929 nuées ardentes deposits, Mt. Pelée, Martinique J. Volcanol. Geotherm. Res., 38 (1929), pp. 77-96

Bourdier et al., 1997a

Bourdier, J.-L., Abdurachman, E.K., Voight, B., 1997a. Flow-surge facies relationships and nuée ardente emplacement at Merapi volcano. IAVCEI General Assembly, Puerto Vallarta, Abst. vol., p. 82.

Bourdier et al., 1997b

J.-L. Bourdier, I. Pratomo, J.-C. Thouret, G. Boudon, P.M. Vincent

Observations, stratigraphy and eruptive processes of the 1990 eruption of Kelut volcano, Indonesia

J. Volcanol. Geotherm. Res., 79 (3-4) (1997), pp. 181-204

Brodscholl et al., 2000

Brodscholl, A.L., Kirbani, S.B., Voight, B., 2000. Sequential dome-collapse nuées ardentes analyzed from broad-band seismic data, Merapi volcano, Indonesia. J. Volcanol.

Geotherm. Res. 100, 363--369.

Clarke and Voight, 2000

Clarke, A.B., Voight, B., 2000. Pyroclastic current dynamic pressure from aerodynamics of tree or pole blow-down. J. Volcanol. Geotherm. Res. 100, 395--412.

Cole et al., 1998

P.D. Cole, E.S. Calder, T.H. Druitt, R. Hoblitt, R. Robertson, R.S.J. Sparks, S.R. Young Pyroclastic flows generated by gravitational instability of the 1996-1997 lava dome of Soufriere Hills Volcano, Montserrat 
Geophys. Res. Lett., 25 (1998), pp. 3425-3428

Escher, 1931

B.G. Escher

Over het vulkanisme van Java in verband met de uitbarsting van den Merapi

De Ingenieur, 37 (1931), pp. A357-A369

Fisher, 1979

R.V. Fisher

Models for pyroclastic surges and pyroclastic flows

J. Volcanol. Geotherm. Res., 6 (1979), pp. 305-318

Fisher, 1995

R.V. Fisher

Decoupling of pyroclastic currents: hazards assessments

J. Volcanol. Geotherm. Res., 66 (1995), pp. 257-263

Fisher and Heiken, 1982

R.V. Fisher, G. Heiken

Mt. Pelée, Martinique: May 8 and 20, 1902, pyroclastic flows and surges

J. Volcanol. Geotherm. Res., 13 (1982), pp. 339-371

Fisher et al., 1980

R.V. Fisher, A. Smith, M.J. Roobol

Destruction of St. Pierre, Martinique by ash cloud surges, May 8 and 20, 1902

Geology, 8 (1980), pp. 472-476

Hadikusumo, 1957

D. Hadikusumo

Report on the volcanological research and volcanic activity in Indonesia for the period 1950-1957

Bull. Volc. Surv. Indon., 100 (1957), p. 122

Hoblitt, 1986

R.P. Hoblitt

Observations of the eruptions of July 22 and August 7, 1980, at Mount St. Helens, Washington

U.S. Geol. Surv. Prof. Pap., 1335 (1986), p. 44

Kelfoun et al., 2000

Kelfoun, K., Legros, F., Gourgaud, A., 2000. A statistical study of tree damage by the November 22, 1994 eruption of Merapi volcano (Java, Indonesia): relationships between ash-cloud surges and block-and-ash flows. J. Volcanol. Geotherm. Res. 100, 379--393. 
Lacroix, 1904

A. Lacroix

La Montagne Pelée et ses éruptions, Masson, Paris (1904), p. 662

Lajoie et al., 1989

J. Lajoie, G. Boudon, J.L. Bourdier

Depositional mechanics of the 1902 pyroclastic nuée-ardente deposits of Mt.

Pelée, Martinique

J. Volcanol. Geotherm. Res., 38 (1902), pp. 131-142

Lavigne et al., 2000

Lavigne, F., Thouret, J.-C., Voight, B., Young, K.Y., LaHusen, R., Sumaryono, A., Suwa, H., 2000. Instrumental lahar monitoring at Merapi Volcano, Central Java, Indonesia. J.

Volcanol. Geotherm. Res. 100, 457--478.

MacDonald, 1972

G.A. MacDonald

VolcanoesPrentice-Hall, Englewood Cliffs, NJ (1972) 510 pp

MacGregor, 1952

A.G. MacGregor

Eruptive mechanisms: Mt Pelée, the Soufriere of St Vincent and the Valley of Ten Thousand Smokes

Bull. Volcanol., 12 (1952), pp. 49-74

Mellors et al., 1988

R.A. Mellors, R.B. Waitt, D.A. Swanson

Generation of pyroclastic flows and surges by hot-rock avalanches from the dome of Mount St. Helens volcano, USA

Bull. Volcanol., 50 (1988), pp. 14-25

Moore and Sisson, 1981

J.G. Moore, T.W. Sisson

The 1980 eruptions of Mount St. Helens, Washington. Deposits and effects of the May 18 pyroclastic surge

US Geol. Surv. Prof. Pap., 1250 (1980), pp. 421-438

Nairn and Self, 1978

I.A. Nairn, S. Self

Explosive eruptions and pyroclastic avalanches from Ngauruhoe in February 1975

J. Volcanol. Geotherm. Res., 3 (1978), pp. 39-60

Nakada and Fujii, 1993

S. Nakada, T. Fujii 
Preliminary report on the activity at Unzen Volcano (Japan) November 1990November 1991: dacite lava domes and pyroclastic flows

J. Volcanol. Geotherm. Res., 54 (1993), pp. 319-333

Neumann van Padang, 1933

Neumann van Padang, M., 1933. De Uitbarsting van den Merapi (Midden Java) in de jaren 1930-1931. Vulkanol. Seismol. Meded. 12, 1-116 (+34 photographs and 7 plates).

Ratdomopurbo and Poupinet, 2000

Ratdomopurbo, A., Poupinet, G., 2000. An overview of the seismicity of Merapi volcano (Java, Indonesia), 1983-1994. J. Volcanol. Geotherm. Res. 100, 193--214.

Shelley and Voight, 1995

Shelley, I., Voight, B., 1995. Medical effects of nuée ardente eruptions: the November 1994 eruption at Merapi Volcano, Indonesia. In: Proceedings of the Merapi Decade Volcano International Workshop, UNESCO/Volcanological Survey of Indonesia, Yogyakarta, p. 9.

Sudradjat and Siswowidjoyo, 1987

A. Sudradjat, S. Siswowidjoyo

Merapi. Annual report of the world volcanic eruptions in 1984, BVE no. 24

Suppl. Bull. Volcanol., 49 (1987), p. 23

Suryo, 1985

I. Suryo

Report on the volcanic activity in Indonesia during the period 1964-1970

Bull. Volc. Surv. Indon., 106 (1985), p. 150

Voight and Davis, 2000

Voight, B., Davis, M., 2000. Emplacement temperatures of the November 22, 1994 nuée ardente deposits, Merapi Volcano, Java. J. Volcanol. Geotherm. Res. 100, 371--377.

Voight et al., 2000a

Voight, B., Young, K.D., Hidayat, D., Subandrio, Purbawinata, M.A., Ratdomopurbo, A., Suharna, Panut, Sayudi, D.S., LaHusen, R., Marso, J., Iguchi, M., Ishihara, K., 2000a. Deformation and seismic precursors to dome-collapse and fountain-collapse nuées ardentes at Merapi Volcano, Java, Indonesia, 1994-1998. J. Volcanol. Geotherm. Res. $100,261--387$.

Voight et al., 2000b

Voight, B., Constantine, E.K., Siswowidjoyo, S., Torley, R., 2000b. Historical eruptions of Merapi Volcano, Central Java, Indonesia, 1768-1998. J. Volcanol. Geotherm. Res. 100, 69--138. 
Voight et al., 2000c

Voight, B., Paripurno, E.T., Farid, L., Bourdier, J.-L., Witono, A., Gautama, E.J., Santosa, H., Abdurachman, E.K., 2000c. Eyewitness accounts of the November 1994 nuée ardente eruption at Merapi Volcano, Indonesia, in preparation.

VSI, 1994

VSI, 1995. Mapping and distribution of November 22, 1994, nuée ardente deposits and assessment of lahar hazard (in Indonesian). Volc. Survey Indonesia, internal report.

Yamamoto et al., 1993

T. Yamamoto, S. Takarada, S. Suto

Pyroclastic flows from the 1991 eruption of Unzen volcano, Japan

Bull. Volcanol., 55 (1993), pp. 166-175

Young et al., 2000

Young, K.D., Voight, B., Subandrio, Sajiman, Miswanto, Casadevall, T.J., 2000. Ground deformation at Merapi Volcano, Indonesia: distance changes, June 1988-October 1995. J. Volcanol. Geotherm. Res. 100, 233--259. 